DOI https://doi.org/10.30525/978-9934-26-039-1-20

\title{
ВЛИЯНИЕ ПРОИЗВЕДЕНИЙ МИРОВОЙ КУЛЬТУРЫ НА ТВОРЧЕСТВО Т. Г. ШЕВЧЕНКО
}

\author{
Исаев Х. Б. \\ доктор филологических наук, \\ профессор кафедры русского языка и литературы \\ Кавказского университета \\ Демьянюк А. А. \\ доктор филологических наук, \\ доиент кафедры русского языка и литературы \\ Кавказского университета \\ 2. Карс, Туриия
}

Т.Г. Шевченко занимает почётное место в мировой культуре. Он постоянно изучал и оценивал достояния мировой культуры и в своих произведениях отобразил значительную часть летописи зарубежных стран.

Великий Кобзарь хорошо знал творчество многих деятелей литературы стран Западной Европы. Круг его увлечений их шедеврами был очень широким.

Особенно ценил поэт произведения В. Шекспира. Он не разлучался с ними на протяжении 15-ти лет своей жизни. 1 февраля 1847 г. в письме Н.И. Костомарову поэт просит отправить ему книги Шекспира [2, с. 291]. Об этом он пишет 11 декабря 1847 г. и в письме А.И. Лизогубу [2, с. 294]. С Нижнего Новгорода, во время возвращения из ссылки 21 января 1858 г. Шевченко пишет М.М. Лазаревскому, чтобы тот купил и отправил ему произведения Шекспира в русском переводе Кетчера [2, с. 396-403]. Поэт любил смотреть постановки пьес великого драматурга, особенно трагедию «Гамлет» и драму «Король Лир». Даже сделал несколько зарисовок, в частности портрет короля Лира.

Большой интерес возник у Шевченко к литературе XVII-XVIII веков. В центре его внимания всегда были Д. Дефо, Д. Свифт, С. Ричардсон и Дж. Макферсон. «Робинзона Крузо» в своей повести «Художник» он назвал «бессмертным творением» [1, с. 478]. Советовал всем читать эту интересную книгу и даже подарил ее старшей дочери своего брата Ефросинии. В письме от 23 марта 1860 г. он напомнил, чтобы племянница внимательно перечитала «Робинзона Крузо» [2, с. 420]. 80 
В повести «Несчастный» Шевченко вспоминает «Путешествия Гулливера» Д. Свифта. Поэта захватывали сказочные картины произведения, тесно соединенные со строгой жизненной правдой $[1$, c. 240$]$.

А вот произведения С. Ричардсона поэта не увлекали, хотя в то время многие читатели считали их шедеврами. Он познакомился с романом «Кларисса Гарлоу» и отметил, что здесь нет ничего важного и существенного - особенно простоты и искренности [1, с. 465].

Произведения Дж. Макферсона Шевченко читал в переводах с английского языка на французский. Ему понравилась обработка старинных кельтских легенд и преданий. В письме Б. Залесскому 6 июня 1854 г. Шевченко утверждает, что произведения Дж. Макферсона читаются с наслаждением [2, с. 333].

С большим интересом относился Шевченко к творчеству В. Скотта. Великий Кобзарь высоко оценил наследие знаменитого романиста, высказываясь о высоком литературном мастерстве автора. В письме М. Осипову 20 мая 1856 г. Шевченко назвал В. Скотта «великим шотландцем» и отметил, что его произведения не напечатаны в достаточном количестве и потому недоступны для широкого круга читателей [2, с. 351].

В повести «Художник» Шевченко пишет, что он прочитал «уже почти все романы Вальтера Скотта» [2, с. 440]. После знакомства с романом «Вудсток, или Кавалер» поэт обратил внимание на тот эпизод, где английский монарх Карл II высоко оценил гостеприимство дочери баронессы Ли. Шевченко особенно поразило то, что девушка не знала высокой социальной значимости должности стоящей перед ней личности, а думала, что перед ней простолюдин. Шевченко даже сделал эскиз этой сцены и любезно подарил его К. Брюллову, которому тоже понравился этот эпизод.

Прочитав роман «Антикварий», поэт сравнивает себя с В. Скоттом, который очень любил путешествовать. В первой части «Прогулки с удовольствием и не без морали» Шевченко пишет: «Утро было действительно прекрасное, и я, как Вальтер Скотт, перевесил походную сумку ..., вооружась походною дубинкою, отправился к пруду, к мельницам» [1, с. 538].

Шевченко одним из первых увидел в романтических произведениях В. Скотта признаки реализма. Поэту понравилось, как английский романист описал быт, обычаи, героизм шотландского и английского народов. Особенно высоко оценил Великий Кобзарь изображение 
героической борьбы английского народа против норманнов. Хорошо зная творчество В. Скотта, он многое взял для себя за пример [1, с. 201].

Зачитывался Шевченко и романами Ч. Диккенса. Роман «Жизнь и приключения Николаса Никльби» он назвал «знаменитым романом» [1, с. 410]. Есть доказательства, что поэт познакомился с этим произведением на страницах сборника «Библиотека для чтения» $[1$, c. 441$]$.

По совету К. Брюллова поэт также читал произведения В. Ирвинга известного мастера романтической новеллы, которого считают одним из основоположников литературы США.

Высоко оценил Шевченко произведения Ч. Байрона. В первой части «Прогулки с удовольствием и не без морали» он называет английского поэта «знаменитым», «крупным», «прославленным» [1, с. 498]. Особенно заинтересовался поэт поэмой «Чайльд Гарольд», которая уже в то время была опубликована в русских переводах и в польских переводах А. Мицкевича.

Для Великого Кобзаря было интересным и творчество шотландского поэта Р. Бернса. Он высоко оценил любовь автора к трудолюбивым людям, веру в могущественные силы народа и природные способности человека.

Французская литература занимала важное место в жизни Шевченко. Поэт особенно выделял П.Ж. Беранже и О. Барбье. Оба были его современниками.

Отправляя письмо М.М. Лазаревскому с Нижнего Новгорода 21 января 1858 г., Шевченко просил прислать произведения Шекспира и песни Беранже в русском переводе [2, с. 396]. В «Дневнике» 1 июля 1857 г. он записал, что читал Беранже в переводе Курочкина [1, с. 112]. Очень понравилась поэту песня Беранже «Старый холостяк». Он переписал это произведение в «Журнал» 5 февраля 1858 г. [1, с. 234-235]. Так поступил Шевченко и со стихотворением «Навуходоносор» (запись от 3 апреля 1858 г.), в котором критикуются цари и придворные [1, с. 257-258].

Шевченко любил читать и произведения О. Барбье, особенно понравилось ему стихотворение «Собачий пир», в котором прославляются герои революционных действий 1830 г. в Париже. Это стихотворение поэт переписал в «Журнал» (записи от 16 и 17 сентября 1857 г.). Еще 2 сентября 1857 г. Шевченко записал: «Я предложил А.А. прочесть «Собачий пир» из Барбье-Бенедиктова (Бенедиктов переводчик «Собачьего пира» с французского языка на русский). После перевода был прочитан подлинник, и общим голосом решили, что 
перевод выше подлинника. Бенедиктов не переводит, а воссоздает Барбье» [1, с. 181-185].

Шевченко также был знаком с творчеством В. Гюго и О. де Бальзака. В повести «Несчастный» он вспоминает имя Квазимодо - героя романа В. Гюго «Собор Парижской богоматери» [1, с. 203], а в повести «Музыкант» намекает на привычку Бальзака писать о женщинах зрелого возраста [2, с. 137].

Своего современника французского писателя Э. Сю Шевченко оценивал негативно. Сю написал много романов о жизни французской бедноты. Произведения его имеют мелодраматический, сладкий стиль и лишены социальной остроты, то есть, в них, по мнению Шевченко, есть много неправды. Это не могло не вызвать резкую реакцию Великого Кобзаря и он 7 марта 1850 г. из Оренбурга пишет В.Н. Репниной: «Сю, по-моему, похож на живописца, который, не изучив порядочно ..., принялся рисовать человеческое тело, и чтобы прикрыть свое невежество, он его полуосвещает. Правда, подобное полуосвещение эффективно, но впечатление его мгновенно! Так и произведение Сю, пока читаешь - нравится и помнишь, а прочитал - и забыл. Эффект и больше ничего» [2, с. 307].

Глубоко уважал Великий Кобзарь немецкую литературу, особенно творчество Й.В. Гете и Ф. Шиллера. Шевченко называл Гете «Великим германским поэтом», но вместе с этим он и критиковал Гете за мысль о том, что «надеждой живут ничтожные умы». В «Журнале» 26 июня 1857 г. он записал, что немецкий классик был прав только наполовину. «Надежда, - утверждает поэт, - это самая нежная, постоянная, до гробовой доски неизменная нянька - любовница» [1, с. 101].

Когда Шевченко увидел в поэзиях и драмах Шиллера призыв к свободе, борьбу против самодержавной политики и т.П., то всем сердцем полюбил творчество великого драматурга. В повести «Художник» поэт с увлечением пишет о постановке «Разбойников» Шиллера на русской сцене [1, с. 439].

Великий Кобзарь, перенимая все полезное из других зарубежных культур, стремился не к рабскому подражанию, а к творческому воплощению в жизнь всего того, что вело к гуманизму и общественному прогрессу. Поэт создал собственные неповторимые шедевры и умел ценить мастерство каждого литератора, который желал правды и развивал свой художественный талант. Учась чужеземному, Шевченко не забывал свою, украинскую культуру и поднес ее на мировой уровень. Именно поэтому его шедевры золотыми буквами вписаны в историю человеческой цивилизации и сияют рядом с наследием Микеланджело, 
Рафаэля, Рембрандта, Ван-Дейка, Фидия, Дюрера, Брюллова, Бетховена, Моцарта, Пушкина, Мицкевича и других титанов духа.

\title{
Литература:
}

1. Шевченко Т.Г. Повна збірка творів: у 3 т. Київ: Державне видавництво художньої літератури, 1949. Т. 2. 644 с.

2. Шевченко Т.Г. Повна збірка творів: у 3 т. Київ: Державне видавництво художньої літератури, 1949. Т. 3. 520 с.

DOI https://doi.org/10.30525/978-9934-26-039-1-21

\section{ОСОБЛИВОСТІ СТАНОВЛЕННЯ ТВОРЧОЇ ПОСТАТІ Ю. М. МУШКЕТИКА В УКРАЇНСЬКОМУ ЛІНГВОКУЛЬТУРНОМУ ПРОСТОРІ}

\author{
Ільїна О. В. \\ кандидат філологічних наук, дочент, \\ докторант кафедри української мови \\ Харківського національного педагогічного університету \\ імені Г. С. Сковороди \\ м. Харків, Україна
}

В українській літературі є чимало постатей, які гартують дух кожного представника етносу. Це високі моральні провідники нації, саме їхня творчість спонукає кожну людину до пробудження духовності, моральності, національної ідентичності. У літературі другої половини XX століття однією з таких постатей можна вважати Ю. М. Мушкетика.

Юрій Михайлович Мушкетик залишив яскравий слід в історії розвитку української літератури. Він належить до митців філософської заглибленості. «Вічні питання» $€$ головними в його творчості. Осмислення світу, місця людини в ньому, значення історії для кожної окремої особистості - лише невеличкий перелік лейтмотивів художніх текстів майстра слова. Ю. М. Мушкетик глибоко осмислює дійсність, пропускаючи крізь себе почуття персонажів. Пише він про добу Київської Русі, чи про Коліївщину, чи про Другу світову війну, чи художньо осмислює проблеми сучасності - у всіх творах чітко можна простежити тверду позицію людини, яка чесно йде за своїми духовноморальними принципами. Про виняткову майстерність письменника неодноразово говорили як критики, так і літературознавці, серед яких 84 